\title{
Sumber Daya Alam dan Kearifan Lokal sebagai Rasional dalam Workshop Visual branding Kawasan Wisata Pantai Plentong Kabupaten Indramayu Jawa Barat
}

\author{
Nanang Ganda Prawira ${ }^{1 *}$, Arief Johari ${ }^{1}$, Mega Fitriani Adiwarna Prawira ${ }^{2}$, Eko Susanto ${ }^{3}$ \\ ${ }^{1}$ Prodi Desain Komunikasi Visual, Universitas Pendidikan Indonesia, Jl. DR Setiabudhi No 229 Kota \\ Bandung, Jawa Barat \\ ${ }^{2}$ Prodi Manajemen Bisnis Pariwisata, Sekolah Tinggi Pariwisata Bandung, Jl. DR Setiabudhi No 186 \\ Kota Bandung, Jawa Barat \\ ${ }^{3}$ Prodi Usaha Perjalanan Wisata, Politeknik Negeri Bandung, Jl. Gegerkalonghilir Bandung Barat, \\ Jawa Barat
}

*E-mail: nananggandaprawira62@upi.edu

\begin{abstract}
Abstrak - Pengembangan pariwisata di Pantai Plentong Desa Ujunggebang Kecamatan Sukra Kabupaten Indramayu telah menunjukkan dampak positif terhadap kondisi sosial-ekonomi dan ekologi di wilayah ini. Kolaborasi antara Pemerintah Desa, BUMDES Maju Ujunggebang dan masyarakat secara nyata mampu merubah Pantai Plentong menjadi destinasi wisata yang inklusif bagi masyarakat Pantai Utara Jawa Barat. Untuk memperluas komunikasi pemasaran dan memberikan identitas visual, dirancang sebuah produk visual branding dalam kegiatan Pengabdian Kepada Masyarakat dengan menerapkan metode Design Thinking melalui kegiatan observasi, wawancara dan Focus Group Discussion. Kegiatan ini telah berhasil merancang sebuah produk visual branding yang akan diterapkan pada produk cinderamata sesuai kebutuhan dan minat mitra. Di masa datang, perlu dilakukan pengembangan visual branding pada media komunikasi pemasaran berupa website, signage, dan media sosial untuk memperluas popularitas Pantai Plentong yang pada gilirannya menarik lebih banyak kunjungan dari segmen demografis dan geografis yang lebih luas demi kemajuan destinasi dan masyarakat di Pantai Plentong.
\end{abstract}

Kata Kunci — visual branding; destinasi pariwisata; Pantai Plentong, destination branding

\begin{abstract}
The tourism development on Plentong Beach, Ujunggebang Village, Sukra District, Indramayu Regency has shown a positive impact on socio-economic and ecological conditions in this region. Collaboration between the Village Government, BUMDES Maju Ujunggebang and the community has been able to turn Plentong Beach into an inclusive tourist destination for the people of the North Coast of West Java. To expand marketing communication and provide visual identity, a visual branding product was designed in Community Service activities by applying the Design Thinking method through observation, interviews, and Focus Group Discussions. This activity has succeeded in designing a visual branding product that will be applied to souvenir products according to the needs and interests of partners. In the future, it is necessary to develop visual branding on marketing communication media in the form of websites, signage, and social media to expand the popularity of Plentong Beach which in turn attracts more visits from wider demographic and geographic segments for the advancement of destinations and people on Plentong Beach.
\end{abstract}

Keywords — visual branding; tourism destinations; Plentong Beach, destination branding

\section{PENDAHULUAN}

Kabupaten Indramayu bagian Barat memiliki sebuah wilayah pantai yang berkembang sebagai destinasi pariwisata, dikenal sebagai Pantai Plentong. Terletak di Desa Ujung Gebang, Kecamatan Sukra, Kabupaten Indramayu, Jawa Barat, dikunjungi masyarakat dari wilayah Indramayu, Karawang, Subang, Purwakarta dengan jumlah rata-rata 300 orang pada hari kerja dan 1000 orang di akhir pekan.

Pantai Plentong dengan kontur dataran landai dan ombak yang relatif rendah menjadi daya tarik pengunjung dari segmen mass tourist [1] khususnya keluarga. Aktivitas berenang, sightseeing, berperahu serta rekreasi pantai diminati segmen tersebut karena dianggap cukup aman dan memberikan pengalaman yang baik. Pantai ini juga dikenal sebagai destinasi wisata dengan harga yang ekonomis, harga tiket masuk sebesar Rp. 10.000 per orang menjadikan pantai ini sebagai destinasi pariwisata inklusif bagi masyarakat Pantai Utara Jawa Barat.

Pengelolaan aktivitas pariwisata di Pantai Plentong dilakukan oleh Badan Usaha Milik Desa 
(BUMDES) Maju Ujunggebang, meliputi inisatif penataan kunjungan hingga pengelolaan SDM dan operasional usaha dengan melibatkan elemen masyarakat Desa Ujunggebang. Atas keberhasilan pengembangan usahanya, lembaga ini meraih penghargaan sebagai BUMDES terbaik tingkat kabupaten dan provinsi. Dalam programnya, BUMDES Maju Ujunggebang menginginkan perluasan aktivitas wisata untuk memperluas segmen pengunjungnya. Selain itu, perluasan usaha dalam produksi cinderamata khas diperlukan untuk memberikan multiplier effect yang lebih luas kepada masyarakat [2].

Untuk mendukung rencana tersebut, pengelola Pantai Plentong memiliki kebutuhan visual branding destinasi wisata sebagai upaya mempengaruhi persepsi pelanggan melalui elemen visual seperti warna, tipografi, bentuk, citra dan sebagainya [3]. Kebutuhan ini sebagaimana diungkapkan pengelola Pantai Plentong untuk memberikan identitas visual yang dapat diaplikasikan dalam berbagai benda. Pada tahap awal, kebutuhan visual branding adalah pada produk cinderamata.

Memperkuat pernyataan kebutuhan di atas, beberapa penelitian mengungkapkan bahwa pelanggan saat ini membuat keputusan berdasarkan emosi dibandingkan logika [4]. Sebuah visual branding yang menarik, mampu membangun kepercayaan dan perasaan positif, terbukti memberikan potensi keunggulan bisnis yang lebih tinggi [5].

Mempertimbangkan kebutuhan tersebut, dilaksanakan kegiatan Pengabdian Kepada Masyarakat yang bertujuan untuk merumuskan, merancang dan memproduksi visual branding Pantai Plentong. Hasil luaran kegiatan berupa visual branding dan konsep cinderamata akan diberikan kepada lembaga pengelola untuk digunakan dan dikembangkan bagi kemajuan destinasi pariwisata Pantai Plentong, Kabupaten Indramayu.

\section{METODE PELAKSANAAN \\ Mengidentifikasi Kebutuhan Mitra}

Kegiatan ini dilaksanakan dengan melakukan survey di wilayah Pantai Plentong dengan kegiatan observasi sumberdaya pariwisata (daya tarik alam, budaya dan buatan) serta aktivitas pariwisata (pengunjung, pengelola, pedagang).

Data kebutuhan mitra dilakukan dengan melakukan wawancara kepada Kepala Desa Ujunggebang, Pengelola BUMDES Maju Ujunggebang dan pelaku pariwisata dan tokoh masyarakat. Konten wawancara mengenai kondisi existing, visi pengelolaan dan kebutuhan terkait pengembangan pariwisata.

\section{Merencanakan Program}

Dilakukan sebagai tindak lanjut kegiatan survey pendahuluan, dilakukan dengan merumuskan program pengabdian kepada masyarakat untuk memenuhi kebutuhan mitra. Untuk mendukung pendekatan kepariwisataan, dilakukan rekrutasi SDM penunjang dari Sekolah Tinggi Pariwisata Bandung dan Politeknik Negeri Bandung yang membidangi bisnis pariwisata dan pemasaran.

Kegiatan perencanaan program dilaksanakan dengan hasil luaran berupa jadwal, materi dan SDM yang akan digunakan dalam kegiatan lapangan. Program disusun dengan kriteria dan peta jalan yang mengarah pada ketercapaian tujuan PKM.

\section{Focus Group Discussion}

Dilakukan diskusi kelompok terfokus bersama pihak Desa Ujunggebang, BUMDES Maju Ujunggebang dan tokoh masyarakat untuk menggali nilai-nilai kearifan lokal, visi dan kepentingan terhadap visual branding Pantai Plentong. Kegiatan ini dimaksudkan untuk mengoptimalkan desain visual branding yang sesuai dengan nilai-nilai masyarakat serta menghindarkan pemaknaan yang keliru atas produk PKM.

Hasil luaran kegiatan ini adalah pokokpokok ide dan rambu-rambu dari stakeholders Pantai Plentong yang tertuang dalam bentuk, warna, typography, dimensi dan aplikasi dalam rancangan visual branding.

\section{Perancangan Visual Branding}

Kegiatan perancangan visual branding Pantai Plentong dengan menggunakan material yang diperoleh dari kegiatan Focus Group Discussion. Kegiatan ini dilakukan dengan menuangkan ide, gagasan, masukan serta nilai dan rambu-rambu sosial yang diberikan peserta FGD Pantai Plentong ke dalam sebuah visualisasi (warna, bentuk dan typography) dengan menggunakan komputer.

Hasil luaran dari kegiatan ini adalah produk visual branding yang disampaikan kepada mitra untuk mendapatkan evaluasi dan persetujuan.

\section{Penyerahan Produk PKM dan Workshop}

Produk PKM berupa visual branding yang telah mendapatkan persetujuan kemudian diserahkan kepada mitra dalam bentuk dokumen elektonik. Untuk memberikan kemudahan kepada stakeholder Pantai Plentong dalam menggunakan produk visual branding, dilaksanakan workshop penerapan produk PKM pada cinderamata.

Hasil luaran dari kegiatan ini adalah tercapainya kompetensi stakeholder dalam 
menerapkan visual branding pada produk-produk cinderamata yang kelak akan diproduksi dan dijual masyarakat Pantai Plentong.

\section{Evaluasi Program}

Dilaksanakan dengan mengukur perkembangan penerapan visual branding pada ragam produk cinderamata oleh stakeholder Pantai Plentong.

\section{HASIL DAN PEMBAHASAN}

Untuk menghasilkan kegiatan perancangan Visual branding yang tepat guna dan tepat sasaran di Pantai Plentong, kegiatan PKM dilaksanakan dengan metode deduktif berupa pengumpulan data, fenomena dan permasalahan mitra melalui kegiatan observasi dan wawancara.

Tahap selanjutnya adalah merumuskan strategi penyelesaian masalah mitra melalui langkah teknis meliputi perencanaan program, desain pendekatan masalah, instrument dan metode pengumpulan informasi, manajemen SDM dan pengadaan peralatan/perlengkapan.

Dengan pertimbangan bahwa visual branding yang akan diterapkan berkaitan dengan barang dan keterlibatan publik, maka dalam proses perancangan sangat memperhatikan nilai-norma dan rambu yang berlaku di Pantai Plentong Desa Ujunggebang sebagai konsideran utama.

Secara khusus, produk perancangan visual branding dilakukan dengan mengaplikasikan konsep Design Thinking tersaji pada gambar berikut

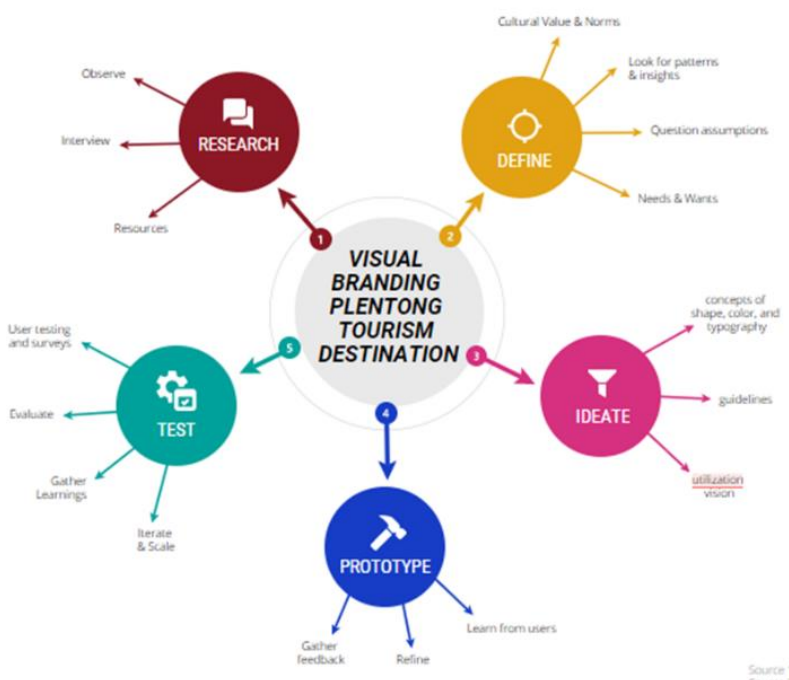

Gambar 1. Design Thinking Kegiatan PKM

\section{Gambaran Aktual Pantai Plentong dan \\ Kebutuhan Mitra}

Untuk menggali kebutuhan mitra secara tepat, dilakukan kegiatan observasi dan wawancara di wilayah Pantai Plentong. Berdasarkan kegiatan tersebut, diketahui bahwa Pantai Plentong dahulunya merupakan wilayah rawan abrasi air alut. Selama 5 tahun terakhir dibawah kepemimpinan Kepala Desa Ujunggebang dilakukan kegiatan perbaikan lingkungan berupa penanaman mangrove dan pembersihan areal pantai sebagai pemenuhan atas visi pemerintah desa menjadikan Pantai Plentong sebagai destinasi wisata yang lebih baik dan memberikan kesejahteraan kepada masyarakat Desa Ujunggebang.

Kegiatan pengembangan pariwisata di Pantai Plentong pada mulanya dilakukan oleh lembaga pemerintahan Desa Ujunggebang, setelah berkembang, dibentuk Badan Usaha Milik Desa Maju Ujunggebang pada tahun 2016 untuk memberikan keleluasaan berusaha dan wadah manajerial Pantai Plentong. Kolaborasi Pemerintah Desa dan BUMDES Maju Ujunggebang secara nyata memberikan terobosan pengelolaan Pantai Plentong dengan program utama penataan lingkungan, penambahan sarana pendukung aktivitas wisata pantai (pembangunan spot foto, sarana interpretasi, visitor management, sarana parkir) serta pengembangan amenitas pariwisata dengan melibatkan masyarakat Desa Ujunggebang.

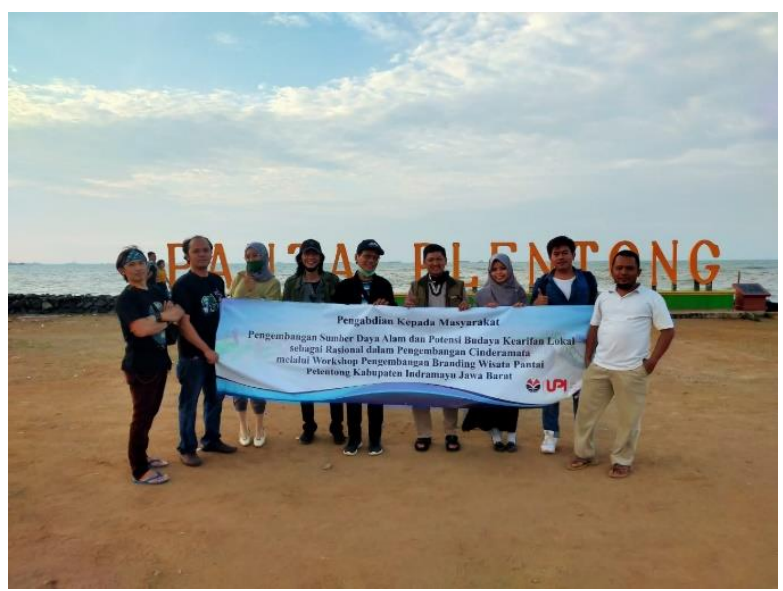

Gambar 2. Kegiatan Observasi Lapangan

Berdasarkan hasil wawancara, masyarakat Desa Ujunggebang semula tidak memandang Pantai Plentong sebagai wahana alternatif penghasilan yang progressif. Mereka bekerja sebagai anak buah kapal, buruh pada sektor pertanian dan pendukung perikanan serta pekerja sektor informal. Setelah pengembangan Pantai Plentong, masyarakat merasakan dampak yang baik terhadap kondisi 
sosial-ekonominya terkait keterlibatan mereka dalam usaha pariwisata.

Hasil kegiatan lapangan menunjukkan data bahwa Pantai Plentong perlu memperluas jangkauan pemasaran dan memperkuat identitasnya sebagai destinasi wisata unggulan di Kabupaten Indramayu. Data BUMDES Maju Ujunggebang menyatakan bahwa pengunjung existing Pantai Plentong berasal dari wilayah Indramayu, Karawang, Subang dan Purwakarta dengan segmen mass tourist dari kalangan ekonomi menengah ke bawah. Untuk memperkuat identitas destinasi, mitra PKM menyatakan kebutuhannya terhadap visual branding yang pada gilirannya akan diterapkan pada cinderamata, signage, website dan sarana komunikasi pemasaran lainnya.

\section{Hasil Focus Group Discussion}

Kegiatan FGD dilakukan bersama perwakilan pengelola Pantai Plentong dan masyarakat Desa Ujunggebang untuk mendapatkan ide pokok, saran dan rambu-rambu dalam perancangan visual branding. Kegiatan ini dilaksanakan dalam bentuk informal untuk memberikan keleluasaan bagi informan mengkomunikasikan ide dan gagasannya.

Berdasarkan data FGD diketahui bahwa komponen visual branding yang diinginkan sebagaimana tersaji pada tabel berikut.

Tabel 1. Hasil Focus Group Discussion

\begin{tabular}{|c|c|c|}
\hline Aspek & Ide Pokok & Alternatif \\
\hline Bentuk & $\begin{array}{l}\text { Bentuk yang mewakili } \\
\text { kondisi geologis, geografis } \\
\text { dan karakteristik Pantai } \\
\text { Plentong sebagai destinasi } \\
\text { pariwisata. }\end{array}$ & $\begin{array}{l}\text { Bentuk } \\
\text { Gelombang Laut, } \\
\text { Bentuk Dataran } \\
\text { Pantai, Bentuk } \\
\text { Nyiur, Bentuk }\end{array}$ \\
\hline Warna & $\begin{array}{l}\text { Warna yang adaptif pada } \\
\text { berbagai jenis media } \\
\text { komunikasi, } \\
\text { merepresentasikan } \\
\text { keinginan maju, keindahan- } \\
\text { kenyamanan dan } \\
\text { memperkuat identitas Pantai } \\
\text { Plentong }\end{array}$ & $\begin{array}{l}\text { Kelompok } \\
\text { Warna Biru, } \\
\text { Kelompok } \\
\text { Warna Hijau dan } \\
\text { Warna Putih }\end{array}$ \\
\hline $\begin{array}{l}\text { Typograph } \\
y\end{array}$ & $\begin{array}{l}\text { Tulisan Pantai Plentong } \\
\text { dengan jenis font yang } \\
\text { mengadopsi nilai-nilai } \\
\text { kedaerahan, dengan besaran } \\
\text { proporsional dan bisa } \\
\text { diaplikasikan secara parsial } \\
\text { sesuai kebutuhan } \\
\text { komunikasi pemasaran. }\end{array}$ & Font Custom \\
\hline
\end{tabular}

\section{Hasil Perancangan}

Dengan mempertimbangkan hasil FGD, observasi dan pengolahan ide secara elektronik, dihasilkan rancangan visual branding sebagaimana tersaji pada gambar 3 dilakukan dengan 2 (dua) pendekatan dalam perancangan desain komunikasi visual yaitu, Making dan Thinking yaitu menangkan nilai-nilai abstrak dari observasi lapangan dan pemaknaan atas informasi verbal yang diperoleh dari hasil FGD. Pembentukan logo dengan landasan Prinsip Gestalt [6] yaitu prinsip saling membangun, saling mengisi, pengasosiasian elemen-elemen sehingga menjadi satu kesatuan utuh.

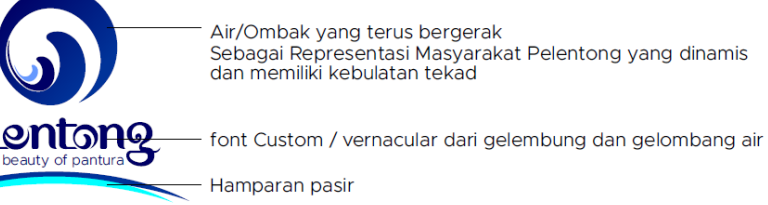

Gambar 3. Rancangan Visual branding Pantai Plentong

Untuk menciptakan keseimbangan diterapkan Prinsip Prosemik [7], yaitu pengaturan jarak dalam membangun PoI (Point of Interest). Beberapa alternatif pengembangan visual branding tersaji pada gambar berikut.
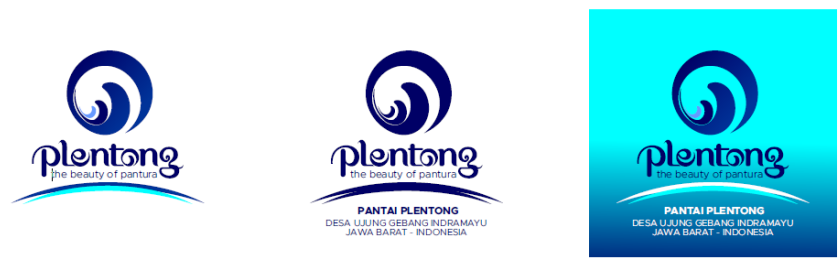

Gambar 4. Alternatif Pengembangan Visual branding Pantai Plentong

Hasil rancangan ini kemudian disampaikan kepada pengelola Pantai Plentong dan mendapatkan persetujuan. Penyerahan hasil rancangan telah dilakukan secara elektronik.

Hasil Workshop dan Evaluasi

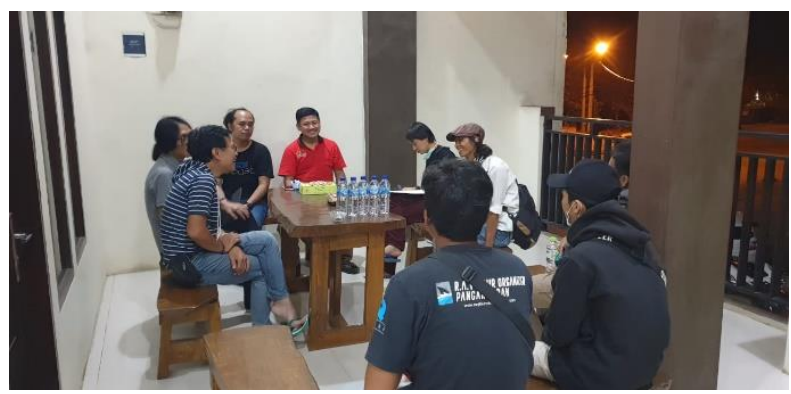

Gambar 5. Diskusi Penerapan Visual branding Pantai Plentong

Untuk mengoptimalkan hasil luaran PKM, dilakukan workshop penerapan visual branding bersama pelaku usaha pariwisata khususnya peminat produksi cinderamata dengan memberikan materi secara informal. Pendekatan informal dilakukan sesuai dengan karakteristik masyarakat 
Desa Ujunggebang yang mengutamakan prinsip kekeluargaan dan menginginkan suasana yang tidak terlalu kaku dalam sebuah kegiatan.

Selanjutnya, Team PKM memberikan materi dan contoh penerapan visual branding pada produk cinderamata sebagai prototype. Diketahui bahwa masyarakat Desa Plentong telah memiliki minat dalam produksi cinderamata dan melihat peluang yang baik untuk menjual produk-produk mereka kepada para pengunjung.

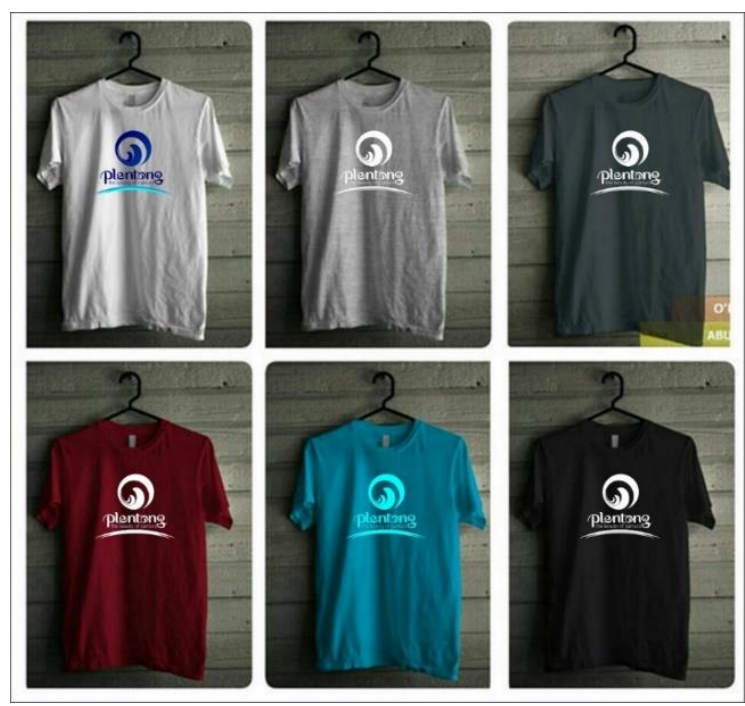

Gambar 6. Contoh Penerapan Visual branding Pantai Plentong

Pengembangan produk cinderamata sebagaimana tersaji pada Gambar 6 diyakini dapat memberikan diversifikasi usaha pariwisata dan memperluas dampak setidaknya pada 2 lapis dampak sesuai konsep multiplier effect yaitu pada aspek produksi langsung dan penyediaan bahan baku/pendukung. Ide cinderamata yang diinginkan adalah produk pakaian dengan branding Pantai Plentong dengan alasan bahwa pakaian merupakan salahsatu kebutuhan primer sehingga market size yang cukup luas, dapat diproduksi secara massal dan memiliki suppy chain yang stabil.

Penerapan visual branding pada produk pakaian akan memberikan manfaat komunikasi pemasaran, dimana produk akan digunakan tidak hanya di lokasi Pantai Plentong, namun akan digunakan di tempat asal pengunjung dan memberikan promosi gratis bagi Pantai Plentong di daerah domisili pengunjung/pembeli cinderamata.

Sebagai bahan evaluasi, Team PKM meminta perwakilan mitra untuk mengembangkan penerapan visual desain pada produk cinderamata. Kegiatan ini sebagai evaluasi atas kegiatan pendampingan yang telah dilakukan sebelumnya. Dari hasil evaluasi, terlihat mitra dapat menerapkan konsep visual branding pada beberapa produk sebagai berikut.

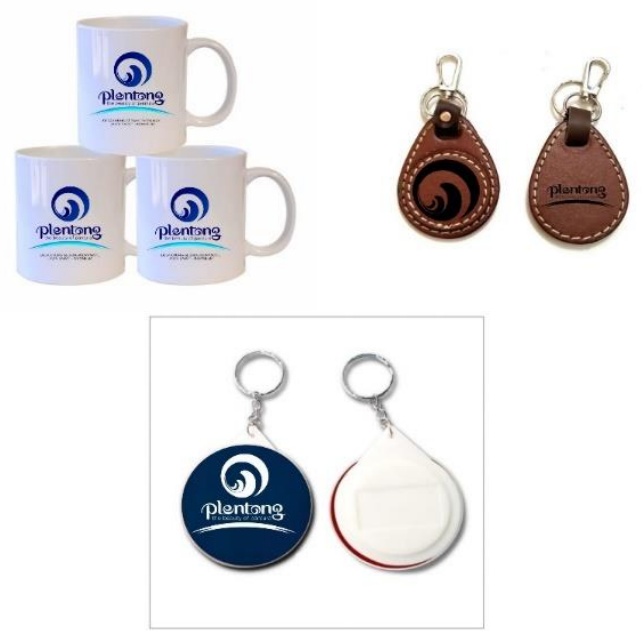

Gambar 7. Hasil Penerapan Visual branding oleh Mitra

\section{KESIMPULAN}

Pengembangan pariwisata di Pantai Plentong Kabupaten Indramayu dapat menjadi contoh bagaimana sebuah destinasi pariwisata berkembang atas kolaborasi yang baik antara Pemerintah Desa, BUMDES dan Masyarakat. Untuk mengembangkan destinasi ke arah yang lebih luas, diperlukan suatu branding dalam memberikan identitas yang jelas bagi pasar potensialnya. Melalui kegiatan PKM telah diserahkan rancangan visual branding beserta contoh penerapan pada produk cinderamata Pantai Plentong. Telah dilaksanakan pula pendampingan dan evaluasi penerapan visual branding dan menunjukkan bahwa mitra telah mampu menerapkan produk PKM ini pada barang-barang cinderamata.

\section{UCAPAN TERIMA KASIH}

Terimakasih atas dukungan seluruh pihak sehingga kegiatan Pengabdian Kepada Masyarakat di Pantai Plentong ini dapat terselenggara. Secara khusus, terimakasih kepada Fakultas Pendidikan Seni dan Desain Universitas Pendidikan Indonesia, Kepala dan Perangkat Desa Ujunggebang, BUMBES Maju Ujunggebang, para informan dan tokoh masyarakat Desa Ujunggebang yang telah mendukung kegiatan Pengabdian Kepada Masyarakat ini.

\section{DAFTAR PUSTAKA}

[1] Cohen, E. (1979). Rethinking the sociology of tourism. Annals of tourism research, 18-35.

[2] Frechtling, D. C., \& Horváth, E. (1999). Estimating the multiplier effects of tourism expenditures on a local economy through a regional input-output model. Journal of travel research, 324-332. 
[3] Dang, L. (2009). Visual branding: A guide to designing visual identity: Case: Plannr. eu.

[4] Bechara, A., Damasio, H., \& Damasio, A. R. (2000). Emotion, decision making and the orbitofrontal cortex. Cerebral cortex, 295-307.

[5] Wiedmann, K. P., Labenz, F., Haase, J., \& Hennigs, N. (2018). The power of experiential marketing: exploring the causal relationships among multisensory marketing, brand experience, customer perceived value and brand strength. Journal of Brand Management, 101-118.

[6] White, B. (2020). Attention, Gestalt Principles, and the Determinacy of Perceptual Content. Erkenntnis, 1-19.

[7] Sykioti, E. (2016). The Semiotics of a 'Different'Advertisement: A Preliminary Study for the Use of Paper Trivets as Advertising Message. Language and Semiotic Studies. 